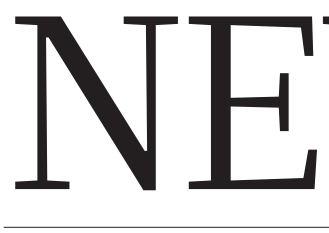

NUCLEAR POWER Plans are

afoot to keep ageing plants

running past 2050 p.16
PALAEONTOLoGY Digital scans could help unravel how famous hominin died $\mathbf{p . 1 9}$
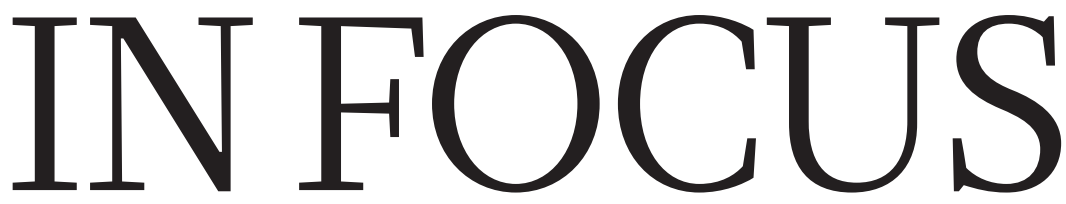

NETWORKS Most mathematicians

hail from just 24 scientific 'families' p.20

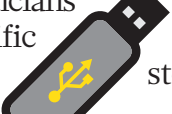

TECHNOLOGY Computing

firms look to DNA to store world's data $\mathbf{p} .22$

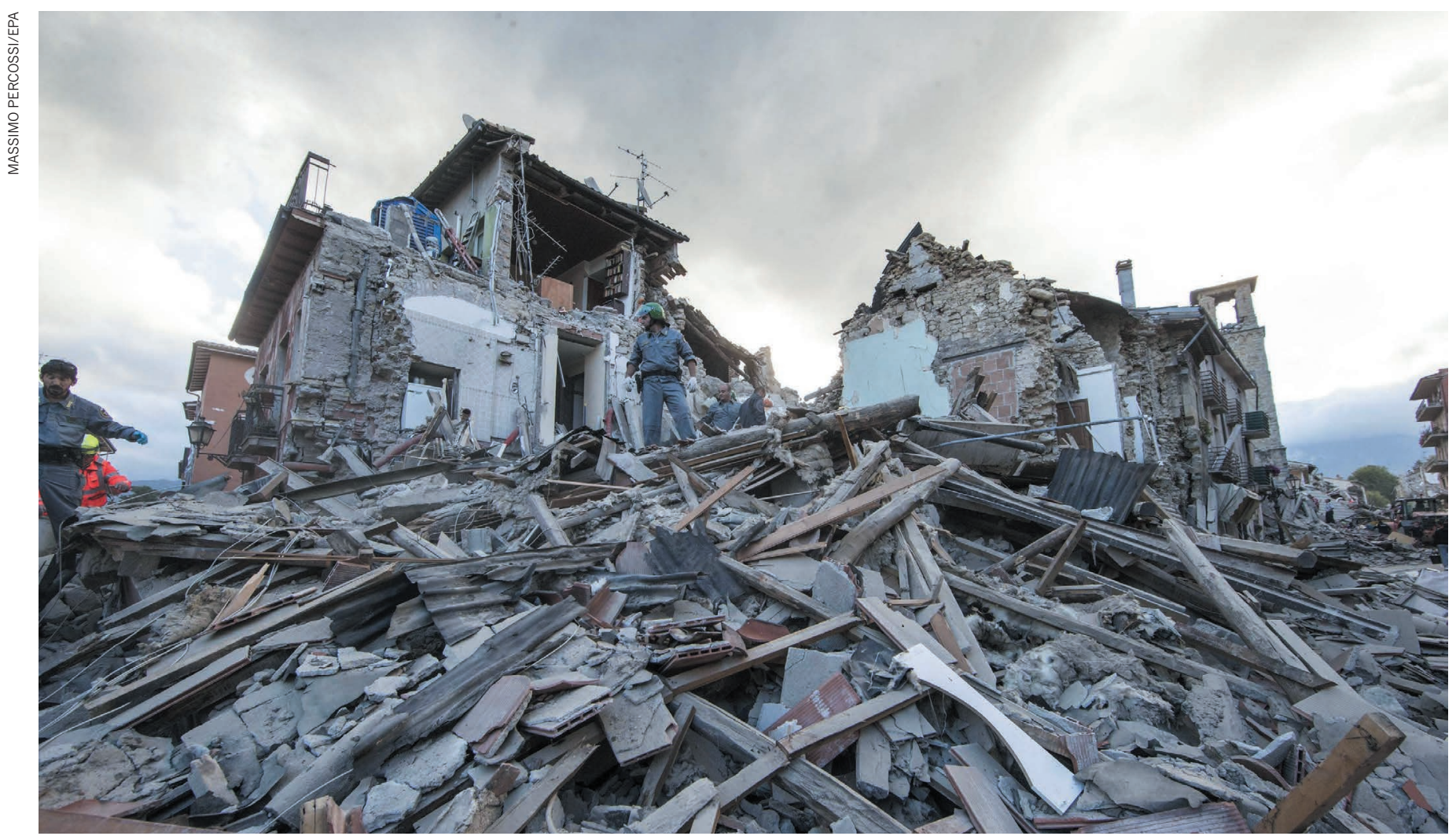

The town of Amatrice in central Italy has been devastated by the earthquake on 24 August.

\title{
SEISMOLOGY
}

\section{Italian scientists shocked by earthquake devastation}

In a region known to be seismically active, destruction on this scale was still a surprise.

BY ALISON ABBOTT AND QUIRIN SCHIERMEIER

A devastating 6.2-magnitude earthquake in central Italy on 24 August that killed more than 290 people was the country's largest since a magnitude- 6.3 earthquake in 2009 that hit the town of L'Aquila, about 40 kilometres away. That event killed 308 people, destroyed tens of thousands of homes and a university. Controversially, it also caused six scientists to be put on trial for manslaughter.

Central Italy's complex geological and tectonic make-up creates a notorious quake risk. The Adria micro-plate dives beneath the Apennine mountain range from east to west, creating seismic strain. The mighty Eurasian and African plates also collide here, with the Eurasian plate moving northeast at 24 millimetres per year.

The latest quake also injured hundreds and laid waste to historic villages in the Apennine mountains, including Amatrice (see
'Epicentre of a quake'). It was a result of increased horizontal stress perpendicular to the mountain chain.

Seismologists had expected a rupture to occur near the location at any time. Still, Giulio Selvaggi, a research director at the National Institute of Geophysics and Volcanology in Rome, and one of those initially convicted of manslaughter - all six were cleared on appeal — says he was shocked by the death and destruction wreaked by last week's 
- quake. The mountainous region around Amatrice is sparsely populated, but the final death toll may exceed that of more populated and urbanized L'Aquila.

Selvaggi seconds a public outcry over the failure of authorities to prioritize making old buildings more earthquake-resistant and notes that his team supplies earthquake maps to them. "We scientists have made a beautiful, detailed seismic hazard map, showing clearly the areas in greatest need of preventive measures," he says. "But public authorities don't take enough action."

The court case over the L'Aquila earthquake came about because a local amateur researcher claimed to have evidence of an imminent, large quake. Six scientists and one government official who had publicly dismissed the amateur's methods were accused of misinforming the public. Following an unprecedented trial, all

\section{EPICENTRE OF A QUAKE}

The earthquake is the strongest in Italy since the magnitude-6.3 event in 2009 near L'Aquila.

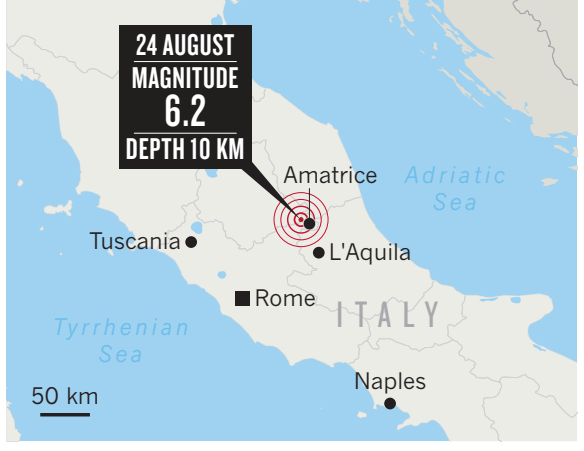

seven were given six-year jail sentences for manslaughter, but the scientists were cleared on appeal in 2014.
Computer scientist Paola Inverardi, who is rector of the university in L'Aquila, says the rebuilding of the university is nearly complete, and that research activities had resumed by 2012 . Science in the region has also benefited from supporting initiatives following the quake, she says. One of these is the Gran Sasso Science Institute, an international graduate school founded in 2012 to inject young intellectual life into L'Aquila. It has been so successful that in June it was awarded university status.

Unlike the earthquake in L'Aquila, which was preceded by frequent, mostly low-magnitude, tremors in the surrounding area, no seismic activity was recorded before the latest earthquake. "It came out of the blue, without the preceding tremors we experienced in 'our' earthquake," says Inverardi. L'Aquila itself experienced virtually no damage, but, she says, "psychologically we were all pushed back".

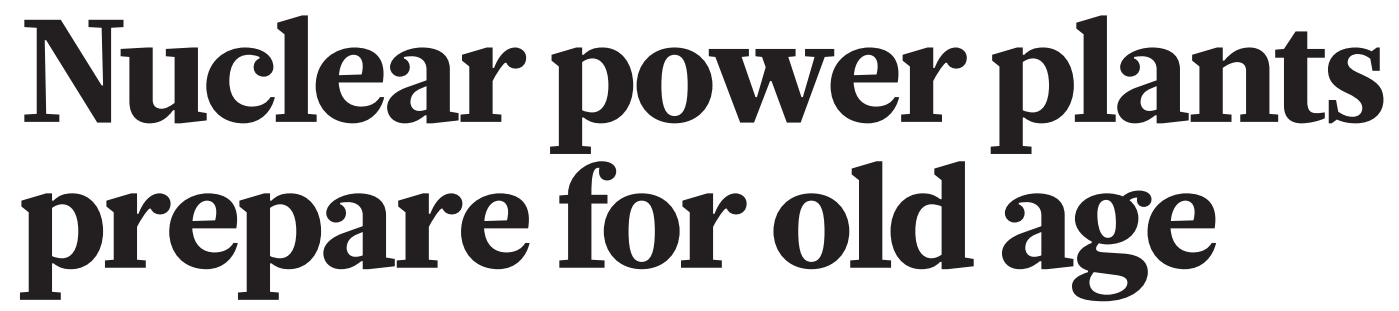

Efforts are afoot to keep the world's reactors running well past 2050.

\section{BY JEFF TOLLEFSON}

ophisticated inspections are helping to

$\mathrm{S}$ pick up defects in ageing nuclear power plants before they cause trouble. In March, ultrasonic tests identified signs of wear and tear in some of the stainless-steel bolts in the reactor core of the Indian Point power plant just north of New York City. Researchers at the Electric Power Research Institute (EPRI) in Palo Alto, California, are now analysing more than a dozen of the 5-centimetre-long bolts - which secure plates that help direct water through the radioactive core - to determine why they failed the inspection.

The analysis comes as the US Nuclear Regulatory Commission (NRC) considers whether to extend the life of Indian Point's two 40 -year-old reactors for 20 more years. Opponents of the plant, including the state of New York, cite the defective bolts, a transformer fire last year and environmental and safety concerns as evidence that the facility should close.

The plant's damaged bolts are just one example of the maintenance issues facing ageing nuclear reactors around the world. The

\section{GOING, GOING, GONE}

Nuclear power accounts for $20 \%$ of US electricity generation, but few new reactors are being built.

The following shows the total projected energy output of these plants under different licence-renewal plans.

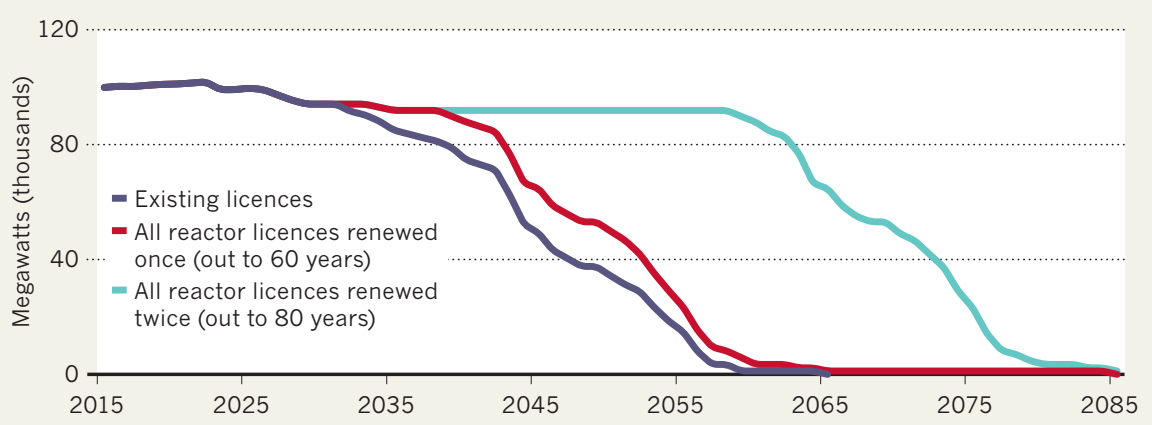

International Atomic Energy Agency and the NRC are developing management guidelines for these facilities, but the problem may be most acute for the United States, whose fleet of 99 reactors is the oldest and largest.

The NRC has renewed the licences of 81 US reactors still in operation for another 20 years. And it presented safety guidelines in December for utilities considering renewing their licences for another 20 years. But concerns remain about the effects of time on facilities that could be in operation for 80 years (see ‘Going, going, gone’).

Former NRC chair Allison Macfarlane says that the industry has been struggling economically in the face of cheap natural gas, and that many nuclear power companies are investing the bare minimum when it comes to maintenance and upgrades. She would rather see a transition to newer - and safer - reactor designs than attempts to push old ones to their limits.

\section{EXTENDING LIFETIMES}

Kurt Edsinger, director of materials at the EPRI, and his team will run a battery of tests on some of the Indian Point bolts to examine fractures and assess the strength of the material. They will also analyse the effects of roughly four decades of neutron bombardment on the crystalline structure of the steel in the bolts. 